\title{
Knitted Resistive Fabric: Properties and Applications
}

\author{
Alexander Oks ${ }^{1}$, Alexei Katashev ${ }^{2}$, Jurij Litvak ${ }^{3},{ }^{1}$ Institute of Design Technologies, Riga Technical University, \\ ${ }^{2}$ Institute of Biomedical Engineering and Nanotechnologies, Riga Technical University, ${ }^{3}$ Politeks Ltd.
}

\begin{abstract}
The presented paper relates to the field of "smart textiles". A new type of knitted strain sensing elements (knitted resistive fabric (KRF)) which can be integrated in the smart garment was developed. KRF was produced from conductive resistive, nonconductive isolating and nonconductive elastomeric yarns. Elastomeric yarn was used as the base yarn and was knitted within the whole fabric, but isolating and resistive yarns (functional yarns) were used as face yarns and knitted in specific sequence. Electrical model of KRF is proposed to describe the behavior of sensing element. The developed KRF has high sensitivity to strain deformation and can be used as local strain sensor or distributed resistive sensing field to control deformation of human body parts, joint motion, respiration etc.
\end{abstract}

Keywords - Conductive yarn, knitting, resistive fabric, smart textiles, strain sensors.

\section{INTRODUCTION}

Smart textile products are widely used in different fields of engineering and everyday life now. For example, smart garments find wide range of healthcare applications, including health monitoring and rehabilitation (1) $-(3)$. The main advantages of such garment in addition to its health monitoring ability is its convenience, possibility of care as for ordinary cloth, including cleaning and washing.

One of the main parts of smart garment is the sensing system which can include one or several sensing elements. To control posture and joint motions, monitoring of respiratory activity, mostly accelerometers and textile strain sensors are used (2) - (10). Unfortunately, application of accelerometers needs their encapsulation and special methods for embedding them into the garment. Textile strain sensors with sensitive elements based on conductive particles, fibers or yarns can be integrated into the garment during the process of garment production. This advantage of textile strain sensors determines the great interest of researchers about their development.

Numerous kinds of technique have been used in order to create strain sensing structures. These sensors have been used to measure human body movements or respiratory activity (4) - (8). References (9) and (10) propose strain sensing elements created by coating Lycra/cotton fabrics with polypyrrole and carbon loaded rubber. Coated strain sensors made by using different polymer materials with conductive carbon particles are also investigated in (11) and (12). Such sensors may be integrated into the garment by using special printing methods. The proposed conductive polymer materials despite the simplicity of their manufacturing have essential drawbacks: their sensitivity, strain and resistive properties strongly vary with time and some of them show a high response time to applied mechanical load.
Another approach to creation of textile strain sensors is proposed in (13) - (17) and others. Sensors are manufactured using the knitting method: conductive yarn is knitted into ordinary fabric. Plain (13) - (16) or rib (17) stiches are used. The deformation of knitted loops causes variation of electrical resistance of the knitted structure. The development of knitting machinery and technology gives the possibility to knit such sensors and integrate them into the garment during the process of garment knitting. Thus, this approach reduces the production stage to one step as compared to the application of coated strain sensors. The weak points of the proposed knitted sensors are: comparatively low sensitivity to strain in course as well as in wales direction; and low durability - during extended usage degradation of the conductive parts is inevitable due to the repetitive frictional action between the overlapping yarns (18).

The strain sensor produced by knitting of separate courses of silver coated yarn into the interlock fabric with elastomeric core span Lycra yarn was proposed (18) - (19). It was shown that such type of knitting increases the sensitivity of knitted sensors in course direction and its durability. But such sensors are rather thick. Therefore they can be integrated only into outwear and they are completely insensible to load strain in wales direction.

The primary objective of this new study was to develop a knitted-based strain sensing element with increased sensitivity that widens the area of possible applications.

\section{KNITTING TECHNOLOGY AND THEORETICAL ANALYSIS}

The proposed sensing element-knitted resistive fabric $(\mathrm{KRF})-$ is knitted from conductive resistive and nonconductive isolating yarns together with elastomeric nonconductive thread. Elastomeric thread is the base, but isolating and resistive yarns are facing functional yarns. The fabric is knitted using plain stitch where courses are formed alternately from isolating and resistive yarns.

It is well-known that the application of elastomeric base thread provides the compression effect of knitted structure where loops in course and especially wales directions are tightly pressed to each other in unstretched fabric (20). Fig. 1a) schematically shows the structure of unloaded (unstretched) element of KRF. It can be seen in the figure that due to compressive effect caused by the base elastomeric thread, despite of the course of isolating yarn (white) knitted between the neighboring courses formed by resistive yarn (black), these resistive courses contact each other in points $a-j$. Due to such contact, the unloaded sensing element of KRF has electrical conductivity.

The element's equivalent resistance $R_{e}$ may be calculated using Holm's contact theory (21). The contact resistance $R_{K i}$ between two adjacent conductive loops is equal to 


$$
R_{K i}=\frac{\rho}{2} \sqrt{\frac{\pi H}{p_{i}}},
$$

where $i$ is the number of the contact points, $\rho$ and $H$ is electrical resistivity and hardness of the contacting materials and $p_{i}$ is contact pressure. The total contact resistance between the neighboring conductive courses of KRF element is equal to

$$
R_{K}=\sum_{1}^{2 n} R_{K i},
$$

where $n$ is the number of wales. Fig. 1b) shows the equivalent electrical circuit of unloaded KRF element.

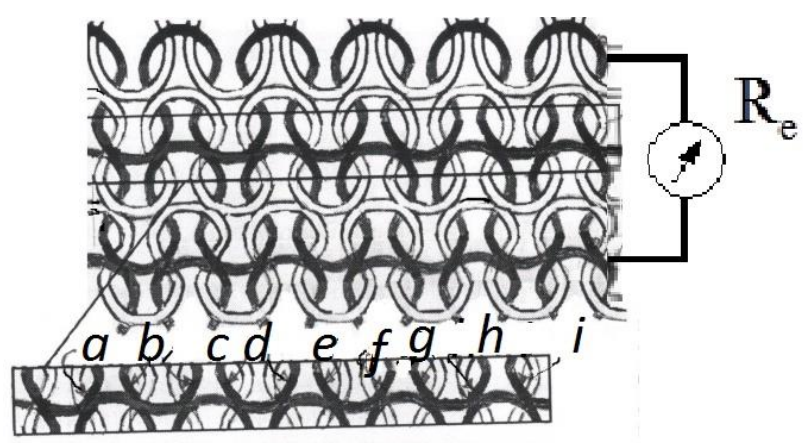

a)

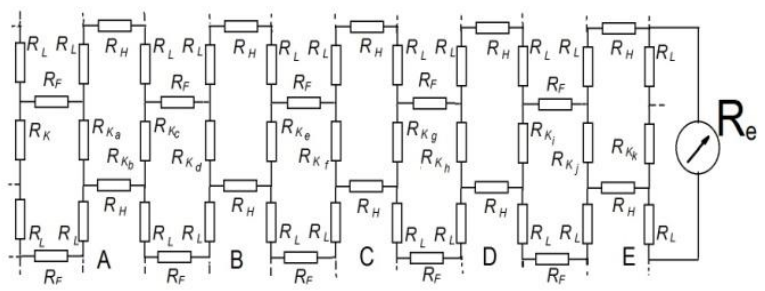

b)

Fig. 1. a) Structure of the unloaded KRF element; b) corresponding equivalent circuit: white - isolating yarn; black - resistive yarn; $R_{H}$ - resistance of needle loop; $R_{f}$ - resistance of sinker loop; $R_{L}$ - resistance of loop leg; $R_{K i}-$ contact resistance at the point $i$.

Equivalent resistance $R_{e}$ can be calculated by taking into consideration resistance of the loop elements $R_{H}, R_{f}, R_{L}$ of two neighboring courses formed from the resistive yarn and total contact resistance $R_{K}$ from (2).

Application of tension load in wales direction causes gradual decrease of contact pressure between the neighboring courses formed from the resistive yarn (Fig. 2a)) and, due to that, partial or complete interruption of electrical contact between conductive courses. Such behavior of KRF is illustrated by equivalent electrical circuit of loaded KRF element (Fig. 2b)). Gradual increase of the load in wales direction leads to a gradual increase of contact resistance $R_{K i}$ and, therefore, equivalent resistance $R_{e}$, too. In some cases resistance of the stretched KRF tends to infinity.
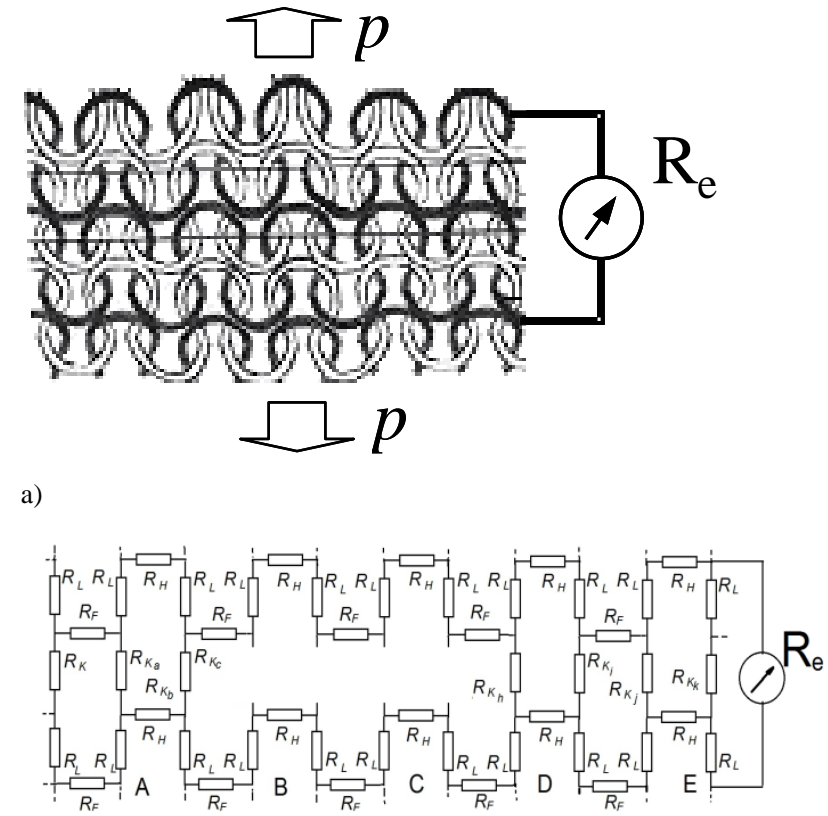

b)

Fig. 2. a) Structure of the stretched KRF element; b) corresponding equivalent circuit: white - isolating yarn; black - resistive yarn; $p$ - applied load.

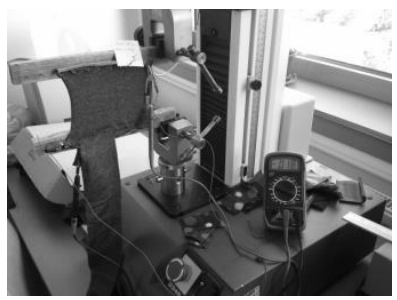

a)

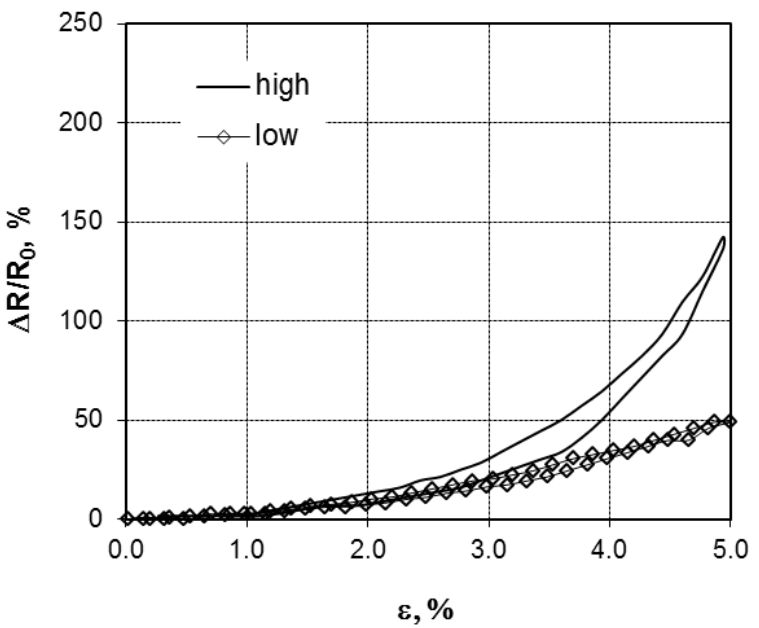

b)

Fig. 3. a) Experimental setup: b) Typical resistance change $R_{0}$ of tubular and plain fabric due to elongation $\Delta l$ (fabric with Shieldex ${ }^{\mathbb{B}}$ Dtex110x2, course density 16 , tubular two layered fabric - width 78 wales, plain- 156 wales) 


\section{EXPERIMENTAL INVESTIGATIONS OF KRF}

\section{A. Materials and Methods}

KRF was knitted by using a two system small diameter circular knitting machine (gauge 14, 156 needles). The experimental fabric was made of pneumoconnected elasthane/polyester 22/78 yarn (base yarn), 25 Tex cotton yarn (functional non-conductive yarn) and two different types of Shieldex ${ }^{\circledR}$ yarn (functional resistive yarn): Shieldex ${ }^{\circledR}$ Dtex 110 and Dtex $110 * 2$. The knitting density of the specimens was varied as well. Knitted KRF fabric was tested as double layered tubular fabric of 78 wales width and also was cut into one layered sheet samples with different width of 156,78 and 39 wales. Specimens of $10 \mathrm{~cm}$ length were stretched using INSTRON ${ }^{\circledR}$ tension measurement machine, while electric resistance was measured by custom-made device, based on BioRado150® telemetric device (Fig. 3) Load and KRF resistance measurements were made in wales direction.

\section{B. Results}

Fig. 4 presents the example of KRF under different loading conditions. It can be seen that in the case of unstrained KRF courses of conductive loops are tightly compressed. Application of tensile loading leads to gradual disconnection of conductive courses as was predicted by theoretical analysis of system behavior in Section II.

a)

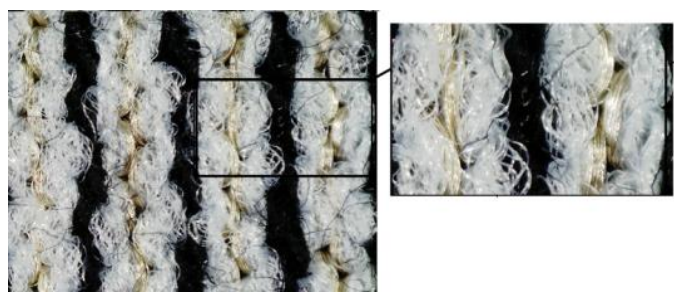

b)
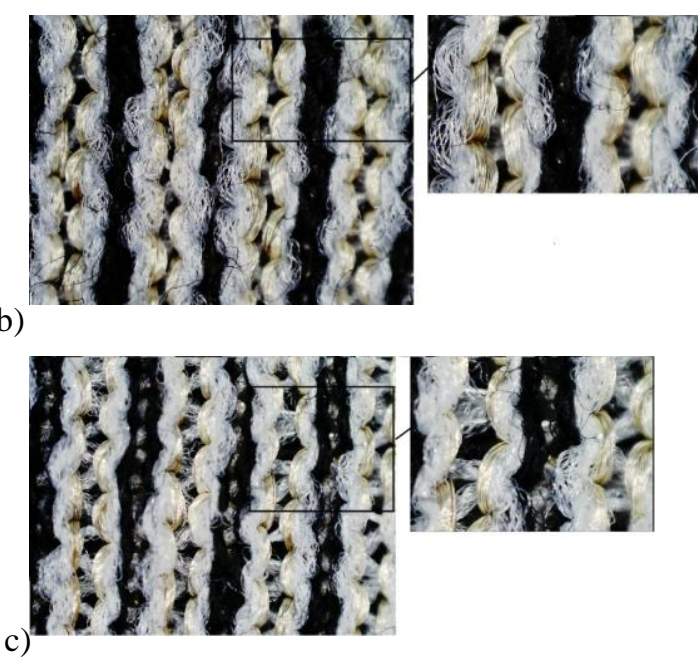

Fig. 4. Example of knitted resistive fabric with different relative extension $\varepsilon:$ (a) $-\varepsilon=0$, (b) $-\varepsilon=5$, (d) $-\varepsilon=20$. Light - conductive resistive yarn, black non-conductive isolating yarn.

Experimental results - regularities "relative change of KRF resistance vs. strain" $\Delta R / R(\varepsilon)$ are shown in Fig. 5, Fig. 6 and
Fig. 7. Regularity $\Delta R / R(\varepsilon)$ had expressed hysteresis loop during the loading-unloading cycle for all tested samples, the upper branch corresponded to the loading, but the lower - to the unloading of the specimen. But the width of the hysteresis loop depended on the type and width of KRF sample. Such KRF property has to be taken into consideration when developing a sensor-based measurement system of the fabric.

All samples demonstrated high sensitivity of KRF resistance to stretching even for small $(<5 \%)$ elongation, compared with the previously reported data (2) - (5). Experiments also showed that the sensitivity of KRF depends on the type of the conductive yarn, fabric course density (Fig. 5), dimensions of sensing element (Fig. 6). Therefore by changing these parameters it is possible to choose the necessary sensitivity of KRF. Also by controlling the pre-loading of the KRF sensor it is possible to move the device to the region of higher or lower sensitivity. It can be seen from Fig. 7 that for certain preloading the gauge factor of KRF may exceed 1000 (Fig. 7a)). Dynamic range of the absolute elongation, measured by the sensor, may be easily controlled by the active length of the KRF sensor: for reasonable sensor length $30 \mathrm{~mm}-100 \mathrm{~mm}$ the range could be $0.3 \mathrm{~mm}-5 \mathrm{~mm}$ that is sufficient for numerous applications.

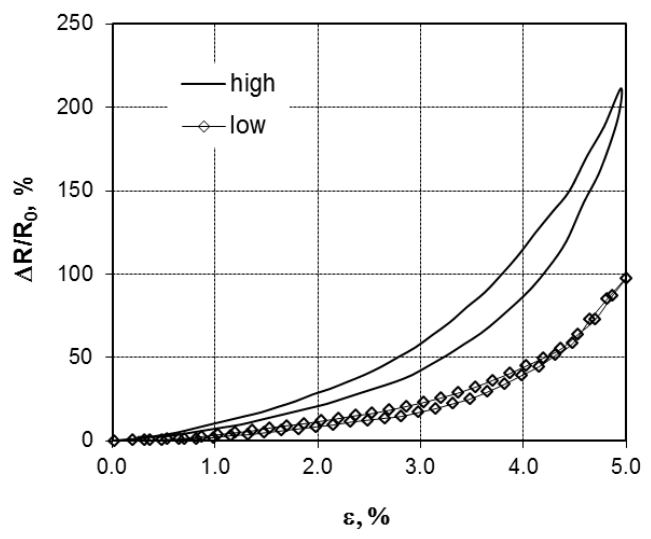

a)

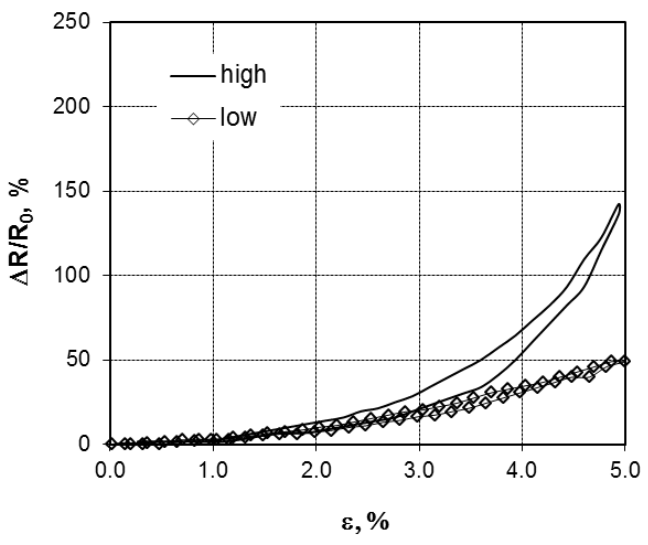

b)

Fig. 5. Relative resistance change $\Delta R / R_{0}$ vs. elongation for materials of different density: a) fabric with Shieldex ${ }^{\mathbb{B}} 110 \mathrm{Dtex}$, low course density $15.2 \mathrm{~cm}^{-1}$, high course density $16.8 \mathrm{~cm}^{-1}$; b) fabric with Shieldex ${ }^{\circledR} 110$ Dtex*2, low course density $15.2 \mathrm{~cm}^{-1}$, high course density $16.8 \mathrm{~cm}^{-1}$. 


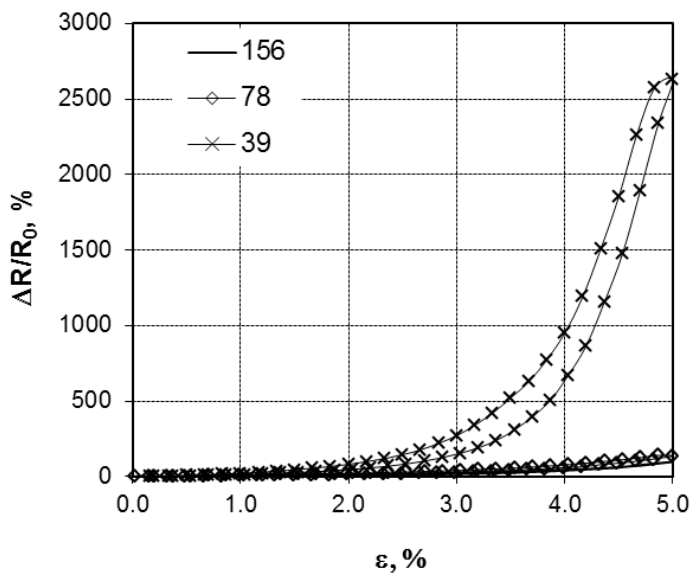

Fig. 6. Relative resistance change $\Delta R / R_{0}$ vs. elongation for plane fabric sheet of different width in wales. Shieldex ${ }^{\circledR} 110$ Dtex, course density $15.2 \mathrm{~cm}^{-1}$.

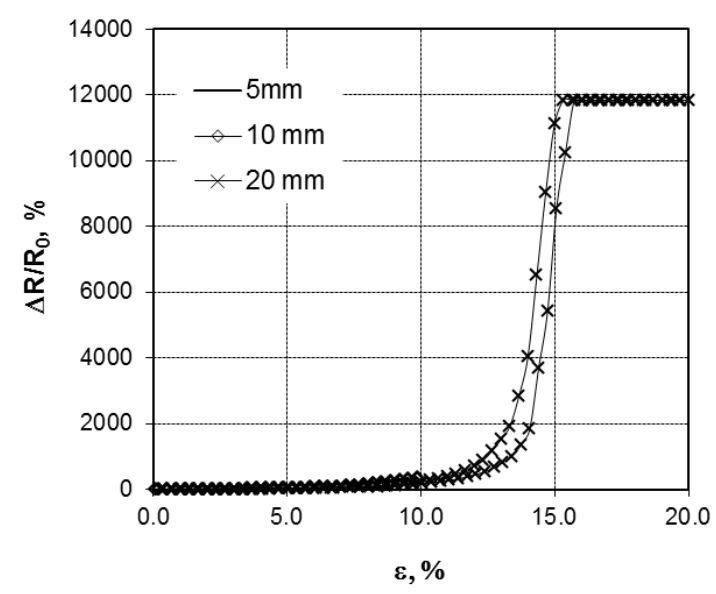

a)

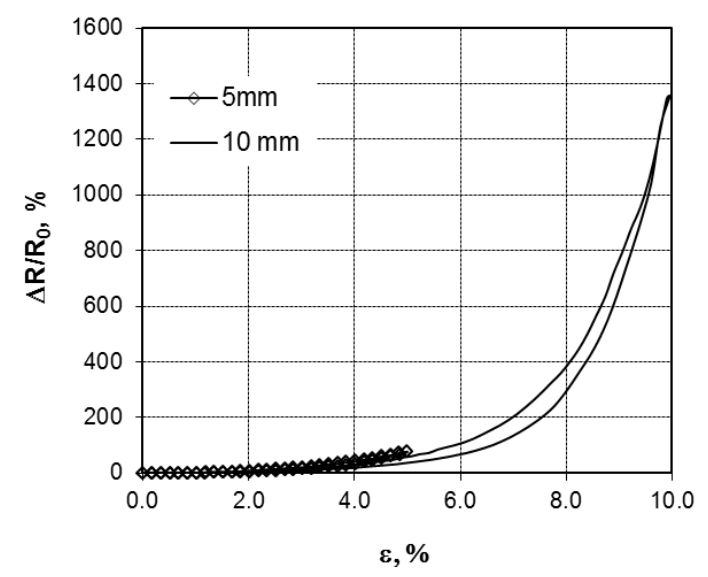

b)

Fig. 7. Relative resistance change $\Delta R / R_{0}$ vs. elongation for different elongation ranges for plane fabric sheet of width 36 wales. a) Shieldex ${ }^{\circledR} 110$ Dtex, course density $15.2 \mathrm{~cm}^{-1}$; b) Shieldex ${ }^{\circledR} 110$ Dtex $* 2$, course density $15.2 \mathrm{~cm}^{-1}$.

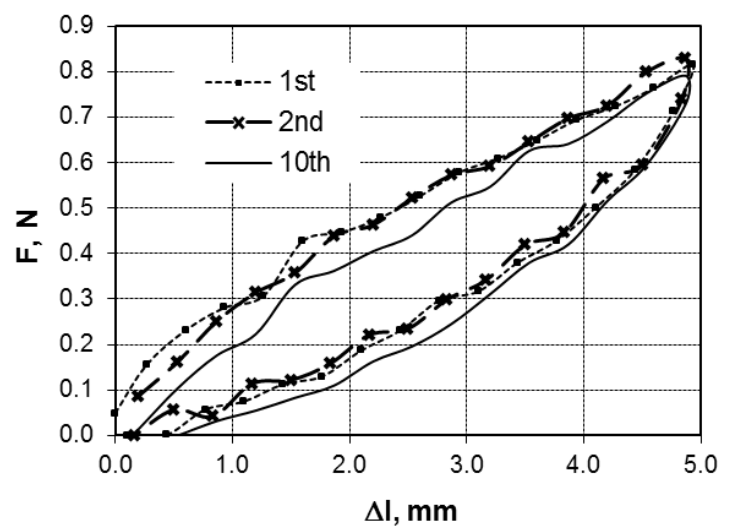

a)

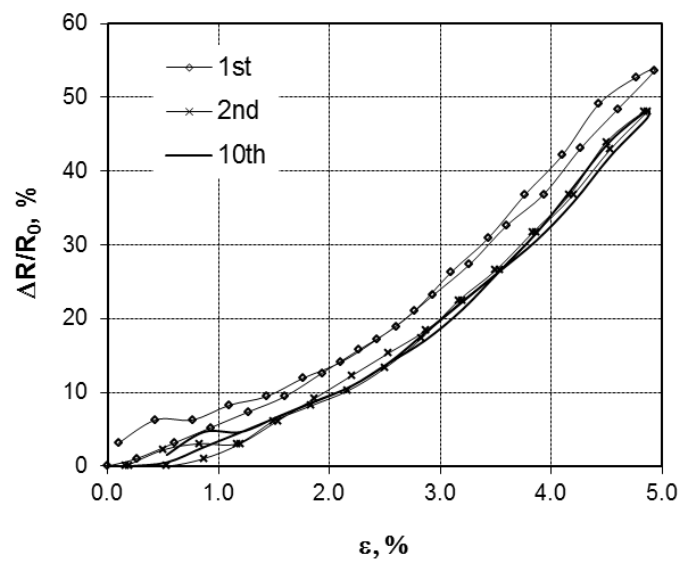

b)

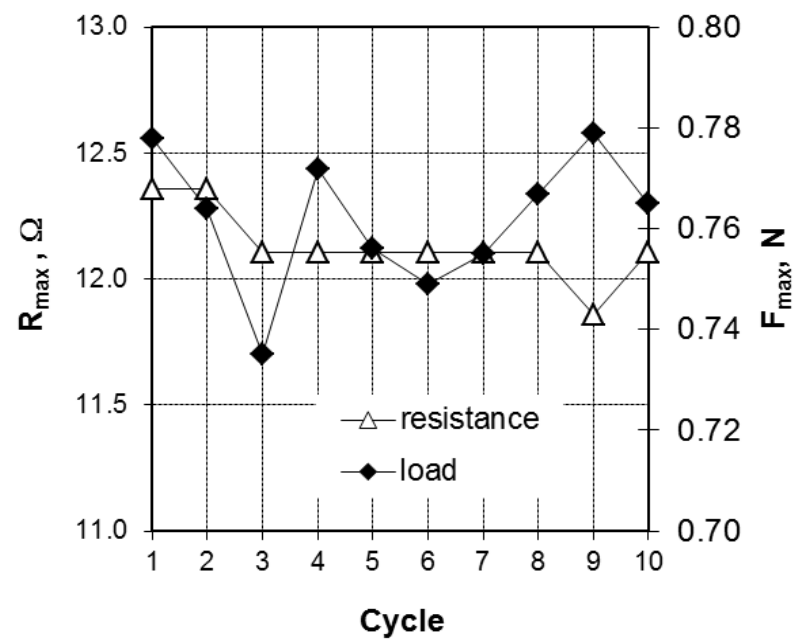

c)

Fig. 8. a) Tension force $\mathrm{F}$ and b) relative resistance change $\Delta R / R_{0}$ vs. elongation for cyclic load. c) Variation of the tension force and resistance at maximal elongation during repetitive load. Plane fabric sheet of width 156 wales Shieldex ${ }^{\circledR} 110$ Dtex, density $15.2 \mathrm{~cm}^{-1}$ 
Sensor stability to periodic strain deformation was investigated, too. Fig. 8 shows the results of cyclic loading of KRF sample.

The analysis of the experimental data showed, that KRF structure has comparatively high stability to cyclic loading. Only during the first cycle of loading KRF demonstrates essential deviation in the form of hysteresis loop and the values of tension force and resistance in comparison with other loading circles. It is explained by the initial compressed state of the fabric before the experiment is started. From the second circle of variation of sensor output signal data are less than $4.5 \%$ of average value.

\section{APPLICATIONS OF KRF}

The developed KRF may be used as a sensing element, integrated into the garment in specified monitored zones. Another application is the use of resistive fabric for production of electro sensitive garment. In the last case KRF forms a distributed resistive field which can be used for controlling the motions of joints and body. To validate the last concept, two prototypes were manufactured for future research: a sensing glove and a sensing sock (Fig. 9). One could expect that measurements of variation in resistance between different points of these items would give possibility to monitor even small motions of fingers and foot joints.

a)

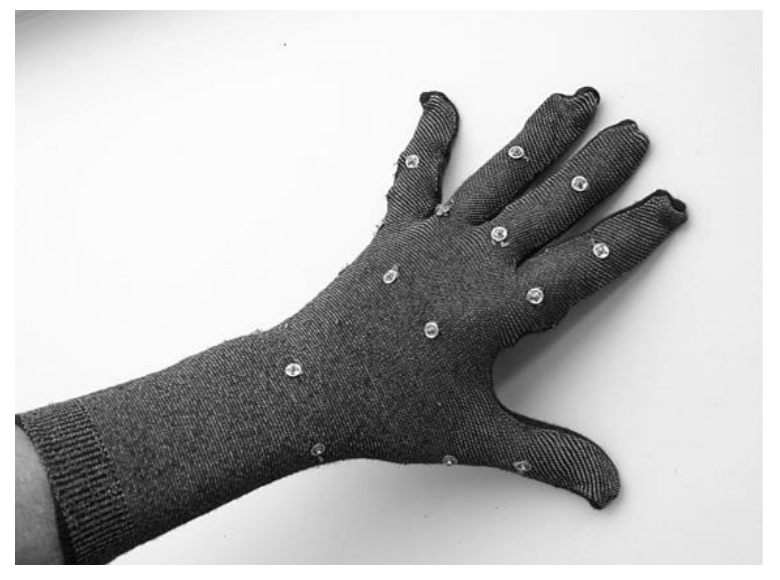

b)

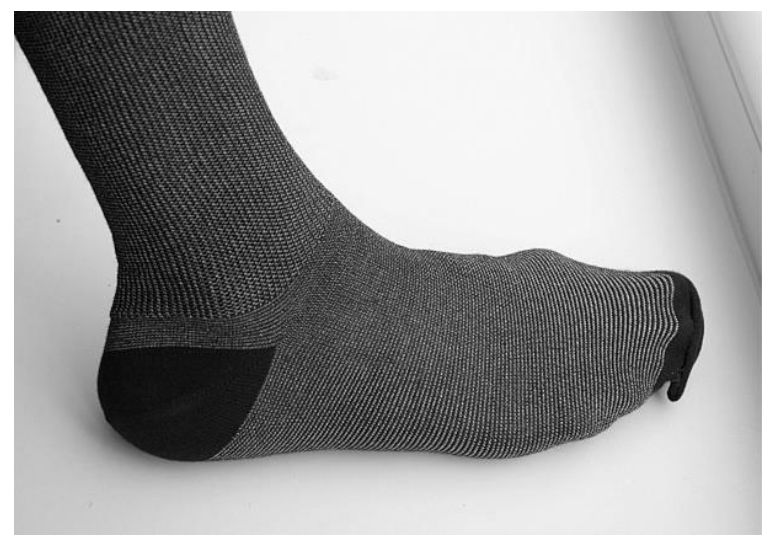

Fig. 9. Examples of application of the sensing fabric: a) sensing glove; b) sensing sock.

\section{CONCLUSION AND FUTURE INVESTIGATION}

The new type of KRF with high sensitivity of ohmic resistance to the strain deformations was developed. The maximal loading sensitivity of the elements may be controlled by selection of resistive yarn, density of courses and size of the sensing area. Knitted fabric may be used as sensing element integrated into garment and as the material for manufacturing of garment with distributed resistive field, the latter may be used for capturing of body motion. Further research includes optimization of KRF sensitivity by using different type of stitches, development of garments for body motion capture and algorithms of KRF data analysis.

\section{REFERENCES}

1. Hoffmann, T., Eilebrecht, B., Leonhardt, S. Respiratory monitoring system on the basis of capacitive textile force sensors. IEEE Sensors J., 2011, vol. 11, pp. 1112-1119. http://doi.org/d3f92r

2. Pacelli, M., Loriga, G., Paradiso, R. Flat knitted sensors for respiration monitoring. In: Proceedings of the IEEE International Symposium on Industrial Electronics, ISIE. Spain, Vigo, 4-7 June 2007. http://doi.org/dpkpt8

3. Mattmann, C., Amft, O., Harms, H., et al. G.Troster, F. Clemens. Recognizing upper body postures using textile strain sensors. In: Proceedings of the 11th IEEE International Symposium on Wearable Computers. Boston, MA, 11-13 October, 2007.

4. Huang, C. T., Tang, C. F., Shen, C. L. A Wearable Textile for Monitoring Respiration, Using a Yarn-Based Sensor. In: Proceedings of the 2006 10th IEEE International Symposium on Wearable Computers. France, Montreux, 11-14 October 2006, pp. 141-142.

5. Kim, K., Lee, I. K., Choi, S. S., et al. Wearable Transducer to Monitor Respiration in a Wireless Way. In: Proceedings of 6th International Special Topic Conference on Information Technology Applications in Biomedicine (ITAB 2007). Japan, Tokyo, 8-11 November 2007, pp. 174176.

6. Mitchell, E., Coyle, S., O'Connor, N. E., et al. Breathing feedback System with Wearable Textile Sensors. In: Proceedings of the 2010 International Conference on Body Sensor Networks (BSN). Sigapore, 7-9 June 2010, pp. 56-61.

7. Guo, L., Berglin, L., Wiklund, U., et al. Design of a garment-based sensing system for breathing monitoring. Text. Res. J. 2013, vol. 83, pp. 499-509. http://doi.org/f23d6t

8. Li, X., Zhang, R., Yu, W., et al. Stretchable and Highly Sensitive Graphene-on-Polymer Strain Sensors. Scientific Reports, Nature Publishing Group, UK, London, 2012.

9. Scilingo, E. P., Lorussi, F., Mazzoldi, A.,et al. Strain-sensing fabric for wearable kinaesthetic-like systems. Sensors J., 2003, 3, pp.460-467. http://doi.org/chg3nf

10. Lorussi, F., Scilingo, E. P., Tesconi, A., et al. Wearable Sensing Garment for Posture Detection, Rehabilitation and Tele-Medicine. In: Proceedings of 4th International IEEE EMBS Special Topic Conference on Information Technology Applications in Biomedicine, 24-26 April, 2003. http://doi.org/cfc875

11. Xue, P., Tao, X.M., Kwok, K.W., et al. Electromechanical behavior of fibers coated with an electrically conductive polymer. Text. Res. J. 2004, vol. 74, pp. 929-936. http://doi.org/b7bnmn

12. Mattmann, C., Clemens, F., Tröster, G. Sensor for measuring strain in textile. Sensors, 2008, 8, pp. 3719-3732. http://doi.org/dqkz59

13. Zhang, H., Tao, X., Wang, S., Yu, T. Electro-mechanical properties of knitted fabric made from conductive multi-filament yarn under unidirectional extension. Text. Res. J. 2005, vol. 75, pp. 598-606. http://doi.org/dpfwbw

14. Zhang, H., Tao, X., Yu, T., et al. Conductive knitted fabric as large-strain gauge under high temperature. Sens. Actuat. A: Phys., 2006, vol. 126, pp. 129-140. http://doi.org/bfg65j

15. Wijesiriwardana, R., T. Dias, T., Mukhopadhyay S. Resistive fibremeshed transducers. In: Proceedings of the Seventh IEEE International Symposium on Wearable Computers (ISWC'03). USA, New York, NY, 21-23 October 2003.

16. Li, L., Au, W. M., Li, Y., et al. Electromechanical Analysis of Conductive Yarn Knitted in Plain Knitting Stitch under Unidirectional Extension. In: 
Procedings of Textile Bioengineering and Informatics Symposium (TBIS 2008). Hong Kong, 14-16 August 2008, pp. 793-797.

17. Kun, Y., Guang-li, S., Liang, Z., et al., Modelling the Electrical Property of $1 \times 1$ Rib Knitted Fabrics Made from Conductive Yarns. In: Proceedings of the Second International Conference on Information and Computing Science, 2009 (ICIC'09). UK, Machester, 21-22 May 2009, pp. 382-385.

18. Atalay, O., W.Kennon, W. Knitted Strain Sensors: Impact of Design Parameters on Sensing Properties. Sensors 2014, vol. 14, pp. 4712-4730. http://doi.org/24q

19. Atalay, O., W.Kennon, W., M. Husain, M. Textile-based weft knitted strain sensors: effect of fabric parameters on sensor properties. Sensors, 2013, vol. 13, pp. 11114-11127. http://doi.org/24r

20. Nadeznaja, N., Charovkij, A., Design parameters of looped structure of single jersey knitted fabric with elastomeric yarns. Vestnik VGTU, 2012, vol. 23, pp. 46-54

21. Holm, R. Electric Contacts: Theory and Applications. 4th ed., New York, Springer-Verlag, 1967. http://doi.org/24s

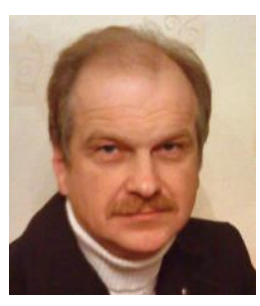

Alexander Oks graduated from Riga Polytechnical Institute in 1980. He received the Degree of Candidate of Technical Sciences in 1985, the Doctoral degree in Technical Sciences of Russia in 1994. He holds the Dr. habil. and Sc.-Eng. degrees. His major field of research is application of knitting technology in medicine and veterinary.

He is a Lead Researcher with Riga Technical University and the Director of the manufacturing company "ESTA". His major fields are: mechanical vibrations and their application in technology and diagnostics; smart textile application in medicine and veterinary.

Address: Institute of Design Technologies, Riga Technical University, Azenes Str. 18, Riga, LV-1048, Latvia

E-mail: siiaesta@gmail.com

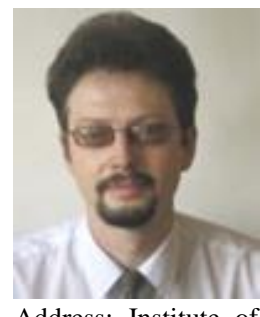

Alexei Katashev graduated from the University of Latvia in 1993. He received the $\mathrm{PhD}$ degree in Solid State Physics in 1998. He is currently a Professor with Riga Technical University.

His major field is biomedical engineering. His research interests are: photogrammetric application for posture assessment, motion capture for breathing analysis, nanostructure of the biomaterial surfaces, nanodosimetry.

Address: Institute of Biomedical Engineering and Nanotechnologies, Riga Technical University, Ezermalas Str. 6k Riga, LV-1006, Latvia E-mail: katashev@latnet.lv

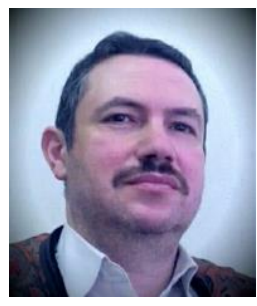

Jurij Litvak graduated from Riga Technical University in 1991 as Engineer of Textile Equipment. His major field is development of hosiery production technology. $\mathrm{He}$ is a co-founder of sock production company "Politeks" and has been the technical director of the company since 1991.

His research interests are: weaving technology by application of innovative yarn processing,

software development for new technologies of sock production, new applications of knitting technology.

Address: "Politeks Ltd.”, Riga, Bauskas Str. 20, LV-1004, Latvia E-mail: politeks@politeks.lv

\section{Aleksandrs Okss, Aleksejs Kataševs, Jurijs Litvaks. Rezistīvā trikotāžas drāna: īpašības un pielietojuma jomas}

Izstrādājumi no "viedtekstila" tiek arvien plašāk izmantoti dažādās tehnikas, tehnolog̣ijas jomās un ikdienā. Jo īpaši aizvien vairāk tas tiek pielietots medicīnā locītavu kustību, sirdsdarbības, elpošanas kontrolē utt. Viena no šādu izstrādājumu galvenajām daḷām ir sensoru sistēma. Pie visplašāk lietojamajiem pieder deformācijas sensori, kuri ir izgatavoti uz tekstila tehnolog̣iju bāzes, it īpaši adītie sensori, kuri tiek integrēti "viedapgèerbos" to izgatavošanas laikā. Šobrīd ḷoti aktuāli uzdevumi ir šo sensoru izturības un jutīguma palielināšana.

Šo uzdevumu risināšanai tiek piedāvāts jauns sensoru tips, kas ir bāzēts uz rezistīvo trikotāžas drānu (RTD), kas ir jutīga pret deformāciju, un to izgatavošanas tehnologija. RTD tiek adīta ar platīnpinumu, kur par bāzes pavedienu tiek izmantots elastomērais dielektriskais pavediens, bet par funkcionālajiem - izolējošie pavedieni un rezistīvie pavedieni, kas tiek ierādīiti noteiktajā secībā. Rezultātā iegūtā cilpu struktūra RTD veido rezistīvo lauku, kuram piemīt augsts jutīgums pret stiepi, pieliktu perpendikulāri adīšanas virzienam. Ir izpētîta gluda pinuma RTD īpašību atkarība no izmantojamā rezistīvā pavediena veida, adīšanas parametriem u.c., RTD jutīguma kontroles iespējas. Ir parādītas RTD izmantošanas iespējas cilvēka roku un kāju locìtavu kustīguma kontrolei.

\section{Александр Окс, Алексей Каташев, Юрий Литвак. Трикотажное резистивное полотно: свойства и области применения}

Изделия из «умного текстиля» все шире используются в различных областях техники, технологии, повседневной жизни. В частности, все большее применение они получают в медицинских приложениях - для контроля движения суставов, сердечной деятельности, дыхания и т.д.. Одной из основных составных частей таких изделий является система датчиков. К наиболее широко используемым относятся датчики контроля деформации, выполненные на базе текстильных технологий, в частности, вязаные датчики, которые интегрируются в «умную» одежду непосредственно при ее изготовлении. Актуальными являются задачи повышения чувствительности и долговечности таких датчиков.

Для решения этих задач предлагается новый тип датчика на базе трикотажного резистивного полотна (ТРП), чувствительного к продольным деформациям, и описывается технология его изготовления. ТРП вяжется платированным переплетением с использованием в качестве базовой эластомерной токонепроводящей нити, а в качестве платирующих (функциональных) - изолирующих и резистивных нитей, провязываемых в определенной последовательности. Получаемая в результате петельная структура ТРП образует резистивное поле, обладающее высокой чувствительностью к растяжению в направлении, перпендикулярном направлению вязания. Исследована зависимость свойств ТРП для переплетения кулирная гладь от вида используемой резистивной нити, параметров вязания и др., возможность управления чувствительностью резистивных характеристик ТРП. Показана возможность использования разработанного ТРП для контроля движения суставов рук и ног человека. 